\title{
Use of Thermography in Reconstructive Surgery Associated With Laser Therapy-Review of Literature
}

\author{
Stephanie Szpoganicz Gambardella ${ }^{1}$, Josiane Morais Pazzini ${ }^{1}$, Julielton Barata ${ }^{1}$, Bruna Fernanda Firmo ${ }^{1}$, \\ Jorge Luis Alvarez Gómez ${ }^{1} \&$ Andrigo Barbosa De Nardi ${ }^{1}$ \\ ${ }^{1}$ Faculdade de Ciências Agrárias e Veterinárias, São Paulo State University (UNESP), Jaboticabal, Brazil \\ Correspondence: Stephanie Szpoganicz Gambardella, Faculdade de Ciências Agrárias e Veterinárias, São Paulo \\ State University (UNESP), Street Professor Paulo Donato Castellane s/n 14884-900, Jaboticabal, SP, Brazil. Tel: \\ 55-179-8189-4164 . E-mail: Stephanie.s.gambardella@gmail.com
}

Received: July 25, 2018

doi:10.5539/jas.v11n6p138
Accepted: November 27, 2018 Online Published: May 15, 2019

URL: https://doi.org/10.5539/jas.v11n6p138

\begin{abstract}
Based on temperature charts, infrared skin thermography is widely used in human medicine, but little known in veterinary medicine. The application of the technique allows orthopedic clinical follow-up as well as aids in the diagnosis of breast tumors in humans, due to its ability to correlate vasculature alterations and tissue vitality with modification of the temperature pattern. For this reason it is applied in veterinary medicine for the detection of joint injuries in horses and animal production, little covering the medicine of small animals. Against of these phages the present study aims to elucidate and suggest its use for the diagnosis and postoperative follow-up of reconstructive surgeries in animals, as well as to evaluate therapeutic measures that seek to improve cutaneous healing, such as low power laser therapy.
\end{abstract}

Keywords: cicatrization, tissue repair, low level laser, flap, vascularization

\section{Introduction}

The importance of understanding and diagnosing physiological processes and pathologies involving disorders of blood circulation in Veterinary Medicine has been increasingly studied. These processes may range from thromboembolism (Hogan et al., 2015) to postoperative complications, such as the loss of flaps in reconstructive surgery (Field et al., 2015).

In addition, attempts to correct and improve these disorders require the use of techniques that promote better blood distribution or recovery of vascularization in affected tissues, such as low-power laser therapy (Cury et al., 2013).

When thinking about animals, we should always take into account the way in which such complications can be diagnosed, especially with regard to stress and the possible consequences of imaging tests, which often require sedation, anesthesia or physical restraint of the patient (Shiel et al., 2012; Zanghi et al., 2013). Stress caused by the veterinary environment and its manipulations can lead to life-threatening injuries, such as reduced immunity, decreased recovery rate (Lloyd, 2017), and thrombosis (Stampfli et al., 2014).

Thinking about these two points a new tool arises in the attempt to circumvent them, infrared cutaneous thermography. Thermography is considered to be a rapid, non-invasive and painless procedure (Tepper \& Gannot, 2015). For these reasons it would rarely require the restraint of the animal, but is still little known by veterinary medicine.

The present study aims to propose the use of cutaneous infrared thermography in the diagnosis and postoperative follow-up of animals, especially those submitted to low power laser therapy. 

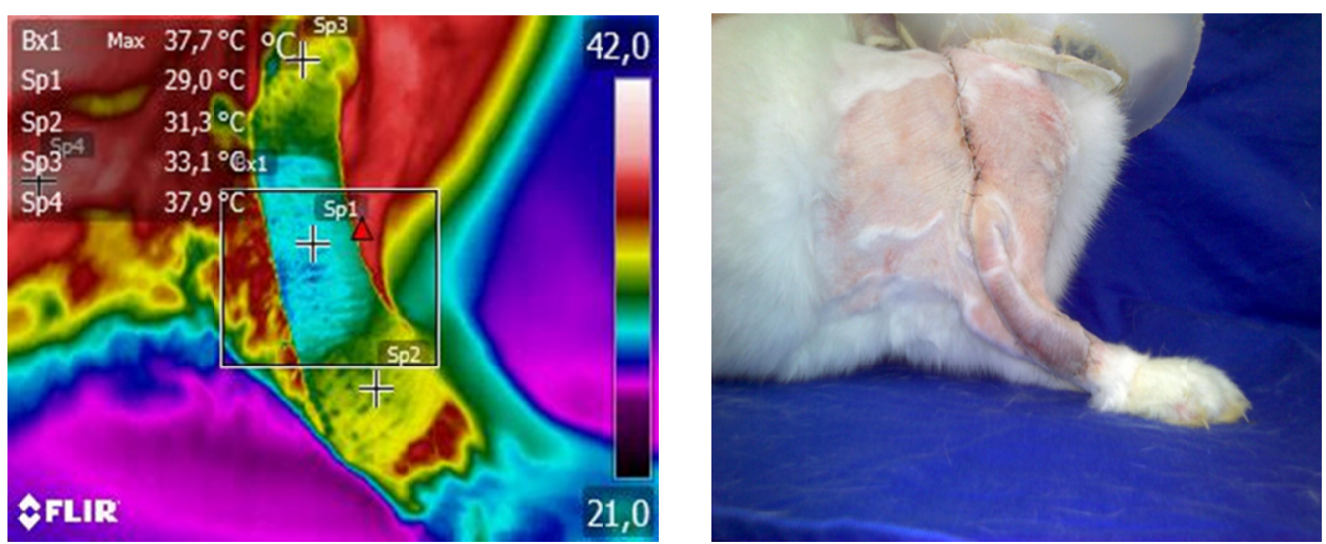

Figures 1. Photographic image of the thermography procedure performed in rabbits (Oryctolagus cuniculus) submitted to reconstructive surgery using tubular flap of subdermal pattern in the thoracic limb. A)

Thermographic image of thoracic limb. Note the temperature difference between the proximal, medium and distal portions of the tube as the color changes. B) Photographic image demonstrating the accomplishment of the surgical procedure. Faculdade de Ciências Agrárias e Veterinárias, FCAV/UNESP, Jaboticabal, SP, 2016

\section{Infrared Thermography}

Radiation is a process characterized by the exchange of heat by means of electromagnetic waves, being observed in the environment as solar and infrared (Dukes, 2007). Every solid object emits electromagnetic radiation at the infrared wavelength and hotter objects emit shorter wavelengths with more emissions per unit time (Hill, 2012). These waves are absorbed by another object, transferring the heat from the warmest (object) to the coldest (Cunnignham, 2004). A fundamental principle in thermal radiation is that the wavelength emitted depends on the surface temperature of the object, and the higher the temperature, the lower the wavelength according to the Stefan-Boltzmann equation (Hill, 2012).

The endothermics have many mechanisms to heat exchange with the enviroment which they live like conduction, convection, radiation and evaporation, (Hill, 2012). These mechanisms are responsible for the loss of up to $75 \%$ of the heat produced and controlled in great part by the vasomotor action (Reece, 2008). The body temperature is directly related to the metabolic rate, since part of its produced energy is transformed into heat. However, the cellular system of vertebrates is considered inefficient, since they are unable to use it as a source to perform work, in this case, biosynthesis or body maintenance, needing to lose it to the environment (Dukes, 2007).

Thermography is a technique based on graphical temperature records provided by infrared irradiation of a body (Figures 1A and 1B), detected by infrared cameras which can be used to evaluate blood perfusion indirectly. It is defined as a rapid, practical and non-invasive method (Barros, 2016), used to obtain early diagnosis in combination with other imaging methods in medicine (Çetinkaya \& Demirutku, 2012). It becomes a useful tool, especially in the field of medicine, since the human eye is only able to see a temperature variable when it becomes higher than 500 degrees Celsius, when metals are reddened by fire for example. Below this temperature we have the spectrum invisible to the eye, the infrared. This spectrum can be detected by infrared cameras, which with the help of software are translated into a color image and can be interpreted by the human eye (Flir, 2018). For this reason it is considered a technique with high sensitivity (up to $100 \%$ ), but with low specificity (on average $44 \%$ ), because the simple temperature change does not distinguish one pathological event from another, being necessary the interpretation from the point of view physician for the findings found to be used as a diagnosis (Radaelli et al., 2014).

\section{Use in Human Medicine}

The technique is used in the evaluation of skin microcirculation of dermal flaps in humans, since the macroscopic aspect of coloration is not always consistent with the reality of post-surgical complications (Schlager et al., 2010) and therefore, it is necessary to evaluate the blood circulation precisely (Slatter, 2007). It can be used during the trans-operative period to evaluate adequate blood perfusion, comparing the technique of Indocyanine Green Video Angiography (Rathmann et al., 2017), as well as the heat distribution of the face through anesthesia using masks, which could prevent the appearance of ulcerations after procedure (Pontes, 2017). 
In addition, it can be used to correlate changes in local temperature with microcirculation dysfunctions in diabetic feet, acting as a predictive agent of ulceration (Brioschi et al., 2007). As well as in the detection of extravasation of chemotherapeutic agents when infused via intravenous, allowing a more precise monitoring of the antineoplastic protocol (Matsui et al., 2017).

However, the most frequent use of thermography in humans is related to the diagnosis of tumors, especially for breast tumors, being considered one of the diagnostic methods with excellent results and complementary to mammography (Milosevic, Jankovic, \& Peulic, 2014; Garduño-Ramón et al., 2017).

For the use of thermography in people, some parameters must be met. The patient should stay away from heat sources such as electrical equipment and windows and stay in the evaluation room with the body area being evaluated previously discovered for fifteen minutes. There should be no airflow, sunlight and hot lamps in the room and it should be monitored for temperature, which needs to be constant. The thermographic device needs to be pre-stabilized for ten minutes. It is important to emphasize that all the results obtained by the use of the thermographer should be evaluated taking into account the clinical history of the patient. Only after all the requirements being met, thermography can become a decisive tool in the evaluation of vascular disorders of the patient (Brioschi et al., 2003).

\section{Use in Veterinary Medicine}

Such as human medicine, veterinary medicine has been employing infrared thermography in several ways. We can highlight the sport animals, especially equines, where the use of the technique allows the evaluation of the mechanisms of thermoregulation, athletic performance and detection of aggressions to tendons, joints and hooves, which could prevent future injuries (Gravena, 2010; Moura et al., 2011; Berkman et al., 2011; Gerardi, 2016). Due to these animals remaining in exposed environments the most diverse temperature variations, it is difficult to obtain the conditions based on the proposals of Brioschi et al. (2003), and a new technique of standardization for temperatures ranging from 64.4 to 95 degrees Fahrenheit was proposed by Basile (2012), called PadTemp, and can be used both clinically and experimentally.

In the production, the use of thermography is very effective both in the evaluation of thermal stress and pathologies associated with the most diverse species. In sheep, the technique was used to evaluate the thermal stress of animals submitted to high temperature conditions in the country, where it was found high for animals suffering from heat (Roberto, 2012). Girardi (2016) demonstrated its efficacy in the early detection of laminitis in sheeps, suggesting its use for this purpose. The same occurs with galliformes, where it was possible to prevent pododermatitis in broiler chickens even before macroscopic lesion detection, correlating the decrease of the local temperature in the points before the appearance of the affection of the legs (Jacob et al., 2016) and evaluation of the thermal stress suffered by birds (Nascimento et al., 2014). In pigs, it was possible to evaluate the stress of piglets in the crèche phase, correlating the ocular temperature increase with the cortisol increase of the animals (Pulido-Rodriguéz et al., 2017). For bovines, thermographic evaluation proved to be useful in the detection of early pampiniform plexus and bull scrotum temperature alterations, which may aid in the reproductive evaluation of animals (Portugal, 2014).

For small animals promising results are presented for orthopedics and neurology areas, evaluating the viability of joints after surgical procedures, comparing the different techniques for knee stabilization (Nina, 2012), as well as the evaluation of lesions and inflammations of knee and spine in dogs, where the uniformity of heat distribution changed, indicating several different temperature points in the animals that had the pathology identified by other imaging techniques (Nomura, 2015), disorders of the intervertebral disc in chondrosystromic dogs (Grossbard et al., 2014) and tenorrhoea in rabbits (Arenhart, 2010).

In the ophthalmology, infrared thermography showed changes in ocular temperature in dogs with dry keratoconjunctivitis (Biondi et al., 2015), whereas in the dentistry area no correlation was found between temperature and the presence of periodontal disease in dogs (Dornbusch, 2013).

In the scope of mammary tumors there are divergences found in the literature. Palveski et al. (2015) found a correlation of breast temperature increase with the presence of tumors, whereas Melo (2013) did not reliably correlate the temperature increase with tumor-induced neovascularization using agNORs, PCNA and VEGF immunological markers, since part of the animals presented reduction of the temperature of the affected breast by conditions not yet clarified, concluding that more studies in the area are still necessary.

In the field of microcirculation, like the reconstructive surgery, some studies have elucidated the possibility of skin infrared thermography being used to monitor dermal and systemic circulation. Carsten et al. (2016) evaluated rats submitted to intoxication by local anesthetics, in the case of ropivacaine, compared to the action of 
the anesthetic with the control group that received saline solution at the same application site, in order to exclude the application stress as a thermal alteration factor. The intoxicate group presented alterations of the dermal microcirculation and peripheral circulation before the manifestation of clinical signs, such as tail hyperthermia, head, dorsum and tail extremity hypothermia. These results suggest the possibility of thermography as a predictive tool in the identifications of microcirculatory disorders, which may be useful in treatment even before systemic alterations or more severe manifestations occur.

Another study evaluated the use of infrared thermography in rats submitted to the surgical technique of a subdermal pattern of the superficial epigastric artery. The animals were divided into two groups, both of which were submitted to the preparation of the flap, which was then fixed in the donor bed and kept in its normal anatomical position. One group had the pedicles attached, while the control group had no blocked blood supply. The images using the thermograph were performed up to 120 minutes after the surgical procedure and showed a greater tempreture of the groups whose artery was attached. The authors concluded that infrared thermography is an excellent technique to follow the surgical post-dermal flap of animals, being able to detect the fall in blood perfusion even before macroscopic changes occurred (Tenorio et al., 2009).

However, the use of thermal images in veterinary medicine is difficult because there is no standardization of suitable conditions for the application of thermography in small animals, and that because the great majority of authors are based on the used parameters for humans, for example ambient temperature standardized at 21-22 degrees and no air currents, as well as no exposure of sunlight through windows or directly, and physical inactivity on the day of the examination (Nina, 2012; Melo, 2013; Novueira, 2015; Palveski et al., 2015). In addition, in dogs and cats the fur may be a problem, since it makes it impossible to evaluate the animals that have fur of medium to long length, since it interferes in the heat irradiation and consequently in the thermographic image (Radaelli et al., 2014). Another complication of the technique is the size of tissue is important. A small size cannot show differences of temperature in different fragments, but the thermography can help monitoring the conditions of a larger tissue or organ, including transport and transplant (Pimentel et al., 2017).

\section{Reconstructive Surgery}

Reconstructive surgery presents wide application in cases of extensive defects caused by trauma, burns, after resection of neoplasms or even in the correction of congenital abnormalities (Pavletic, 2010; Albernaz et al., 2015). Reconstructive surgery techniques consist of subdermal, axial patches, and cutaneous grafts (Pavletic, 2010).

According to Trindade (2009) pedicled skin flaps are considered the best option for dogs and cats, in contrast the grafts are more suitable the human and equine species. Therefore, the knowledge of skin flap techniques promotes great applicability, providing excellent cosmetic results in addition to lower cost when compared to other therapies (Matera et al., 1998).

Among the techniques of reconstructive surgery for animals, there are the axial pattern patches, which have an artery and vein in their constitution, responsible for their blood supply, so the subdermal flaps depend on the adjacent irrigation of the skin, because they do not have an artery and vein in its constitution. The preparation of the subdermal flaps consists of partially with drawing them from the donor bed reaching the recipient bed, thus preserving the vascularity necessary for the vitality of the tissue at its base and ensuring coverage of the defect. The flap should be wider and longer than the defect because its contraction is common due to inflammation, scarring and even necrosis (Castro et al., 2015).

The patches of the subdermal pattern are divided into indirect and direct tubules. The indirect ones consist of a pedicle of dermis and epidermis that are partially withdrawn from the donor bed reaching the recipient bed in the form of a tube, thus preserving the vascularity necessary for the vitality of the tissue at its base and ensuring coverage of the defect. The technique is performed in several steps since the pipe is made indirectly until it is fixed to the defect (Fossum, 2009). In addition, the tubular flap must be developed in such a way that it moves freely in any position without twisting of the pedicle, otherwise tubular irrigation may be compromised leading to ischemia and loss of the same (Slatter, 2007).

Therefore, direct tubular flaps consist of confection of the tubular flap in a single moment, being more predisposed to complications due to vascularization failure (Castro et al., 2015). Aspects of flap coloring are subjective, and can not be correlated with complications. Therefore, the measurement of pedicled flap temperature becomes indispensable to evaluate the circulation precisely (Slatter, 2007). 
The indication of the indirect tubular flaps is that the procedure be performed in several stages, indirectly, until its transposition to the defect. The justification for the reconstruction process to occur in multiple phases is to favor the vascularization of the tube by means of its previous preparation (Castro et al., 2015). In view of the risks involved in the technique, the association of the tubular flap of the subdermal pattern with some postoperative adjuvant therapy that stimulates angiogenesis and increases the chances of success of the technique may be advantageous.

\section{Laser Therapy}

Tissue healing depends on several factors that are not statically subdivided, but occur simultaneously and predominantly. Several chemical mediators such as prostaglandins and macrophages are responsible for each part of this process. The balanced activation of cellular factors such as migration, neovascularization, formation of granulation tissue and metabolic changes such as coagulation result in tissue repair, which finally reestablishes animal homeostasis (Balbino et al., 2005; Oliveira \& Dias, 2012). The failure of these factors or interference in their normal process before surgery is termed as surgical complication, and in veterinary medicine, especially for dermal flaps, include suture dehiscence, edema, total or partial necrosis and infections, compromising healing and consequently the success of the technique, which can lead to complete loss of the surgical procedure (Paulo et al., 2005; Cook \& Thomson, 2014; Field et al., 2015) or consequences such as eviscerations (Oliveira et al., 2000).

In the attempt to improve the healing process of complications suffered by the flaps or even avoid them, several techniques have been studied. These techniques aim to reduce inflammation, promote neovascularization, and improve tissue repair, such as Lithospermum officinale (Amiri et al., 2017), platelet rich plasma (Pazzini et al., 2016) and phototherapies, which include the low-power laser and LED (Corazza \& Jorge, 2007).

Low-power laser therapy promotes improvement in epithelial, bone (Silva et al., 2007) and muscular healing (Garcia et al., 2017). At the microscopic level the benefits include reducing the number of inflammatory cells, increasing the amount of wound fibroblasts and organizing the collagen, conferring a more organized granulation tissue (Rabelo et al., 2006; Rocha Júnior et al., 2006) with faster healing (Dall Agno et al., 2009) and with higher tensile strength (Carvalho et al., 2010).

However, one of the major effects associated with laser therapy is its ability to induce neovascularization when compared to common tissue repair (Rocha Júnior et al., 2006; Corazza \& Jorge, 2007). This fact may favor the treatment of complications of diabetes in animals, increasing the blood supply of the extremities of the limbs (Tatmatsu-Rocha et al., 2016) and, in reconstructive surgery, promote better blood supply of flaps favoring their survival (Cury et al., 2013).

\section{Conclusion}

Infrared thermography is an excellent technique to accompany patients undergoing reconstructive surgery, because it evaluates the integrity of the flaps by means of temperature; moreover, it is also important in patients undergoing low power laser therapy, since it is able to detect its benefits from the correlation of temperature increase with greater vascularization of the flaps when compared to animals that were not benefited by the treatment.

\section{References}

Albernaz, V. G. P., Ferreira, A. A., \& Castro, J. C. (2015). Thermal burns in dogs and cats. Veterinária e Zootecnia, 22(3), 322-334.

Amiri, M., Tanideh, N., Seddighi, A., Mokhtari, M., Amini, M., Partovi, A. S., ... Mehrabani, D. (2017). The Effect of Lithospermum officinale, Silver Sulfadiazine and Alpha Ointments in Healing of Burn Wound Injuries in Rat. World Journal of Plastic Surgery, 6(3), 313-318.

Arenhart, R. (2010). Thermographic and histological analysis of tendon suture in rabbits after active early mobilization (map) (Master's Thesis, Center for Health and Sport Science, State University of Santa Catarina, Santa Catarina, Brazil). Retrived from http://tede.udesc.br/handle/handle/465

Balbino, C. A., Pereira, L. M., \& Curi, R. (2005). Mechanisms involved in healing: A review. Brazilian Journal of Pharmaceutical Sciences, 41(1).

Barros, D. V., Silva, L. K. X., Kahwage, P. R., Lourenço Júnior, J. B., Sousa, J. S., Silva, A. G. M., ... Garcia, A. R. (2016). Assessment of surface temperatures of buffalo bulls (Bubalus bubalis) raised under tropical conditions using infrared thermography. Arquivo Brasileiro de Medicina Veterinária e Zootecnia, 68(2), 422-430. https://doi.org/10.1590/1678-4162-8327 
Basile, R. C. (2012) Methodology of evaluation and analysis of thermography in equines. Faculdade de Ciências Agrárias e Veterinária, São Paulo State University, Campus Jaboticabal, São Paulo, Brazil. Retrived from https://repositorio.unesp.br/handle/11449/118231

Berkman, C., Albernazi, R. M., Basilei, R. C., Lacerda-Neto, J. C., \& Acknowledgments Ferrazi, G. C. (2011). Treadmill exercise did not raise the temperature of the horse's hoof. Ciência Rural Santa Maria, 41(8), 1398-1404. https://doi.org/10.1590/S0103-84782011005000104

Biondi, F., Dornbusch, P. T., Sampaio, M., \& Montiani-Ferreira, F. (2005). Infrared ocular thermography in dogs with and without keratoconjunctivits sicca. Veterinary Ophthalmology, 18(1), 28-35. https://doi.org/10.1111/ vop. 12086

Brioschi, M. L., Macedo, J. F., \& Macedo, R. A. C. (2003). Cutaneous thermometry: New concepts. Jornal Vascular Brasileiro, 2(2), 151-60.

Brioschi, M. L., Mehl, A., Oliveira, A. G. N., Freitas, M. A. S., Macedo, J. F., Matias, J. E., \& Macedo, R. A. C. (2007). Infrared cutaneous thermometry exam in Diabetic foot evaluation. Revista Médica do Paraná, 65(1), $33-41$.

Carstens, A. M. G., Tambara, E., Colman, M., Carstens, D., Márcio, G., \& Matias, J. E. F. (2016). Infrared image monitoring of local anesthetic poisoning in rats. Revista Brasileira de Anestesiologia, 66(6), 603-612. https://doi.org/10.1016/j.bjan.2016.02.004

Carvalho, C. K., Nicolau, R. A., Maia, A. M., Barja, P. R., De Sá, H. P., Santo, L. E., \& Rocha, G. M. (2010). Study of cutaneous cicatricial resistance of rats treated with laser phototherapy. ConScientia e Saúde, 9(2), 179-186. https://doi.org/10.5585/conssaude.v9i2.2267

Castro, J. L. C., Huppes, R. R., De Nardi, A. B., \& Pazzini, J. M. (2015). Princípios e técnicas de cirurgias reconstrutivas da pele de cães e gatos (1st ed.). Curitiba: Medvep.

Çetinkaya, M. A., \& Demirutku, A. (2012). Thermography in the assessment of equine lameness. Turkish Journal of Veterinary and Animal Science, 36(1), 43-48.

Cook, D. A., \& Thomson, M. J. (2014). Complications of the angularis oris axial pattern buccal flap for reconstruction of palatine defects in two dogs: Case series. Australian Veterinary Journal, 92(5). https://doi.org/10.1111/avj.12175

Corazza, A. V., \& Jorge, J. (2007). Photobiomodulation on the Angiogenesis of Skin Wounds in Rats Using Different Light Sources. Photomedicine and Laser Surgery, 25(2), 102-106. https://doi.org/10.1089/ pho.2006.2011

Cunningham, J. G. (2004). Treatise of Veterinary Physiology (3rd ed.). Rio de Janeiro: Guanabara Koogan.

Cury, V., Moretti, A. L. S., Assis, L., Bossini, P., Crusca, J. S., Benatti Neto, C., ... Parizotto, N. A. (2013). Low level laser therapy increases angiogenesis in a model of ischemic skin flap in rats mediated by VEGF, HIF-1a and MMP-2. Journal of Photochemistry and Photobiology, 125, 164-170. https://doi.org/10.1016/ j.jphotobiol.2013.06.004

Dall Agnol M. A., Nicolau, R. A., Liam, C. J., \& Munin, E. (2009). Comparative analysis of coherent light action (laser) versus non-coherent light (light-emitting diode) for tissue repair in diabetic rats. Lasers in Medical Sciece, 24(6), 909-916. Retrived from: https://doi.org/10.1007/s10103-009-0648-5

Dornbusch, L. P. T. C. (2013). Study of the application of thermography in periodontal disease and in apical abscesses in dogs (Master's Thesis, Setor de Ciências Agrárias, Federal University of Paraná. Paraná, Brazil). Retrived from http://hdl.handle.net/1884/35478

Dukes, H. H., \& Swensen, M. J. (2007). Physiology of domestic animals (13th ed.). Rio de Janeiro, RJ: Guanabara Koogan.

Field, E. J., Kelly, G., Pleuvry, D., Demetriou, J., \& Baines, S. J. (2015). Indications, outcome and complications with axial pattern skin flaps in dogs and cats: 73 cases. Journal of Small Animal Practice, 56. https://doi.org/10.1111/jsap.12400

Flir. (2018). What is infrared. Retrived from http://www.flir.com.br/home/news/details/?ID=80767

Fossum, T. W. (2009). Surgery of small animals (3rd ed.). São Paulo: Elsevier.

Garcia, T. A., Camargo, R. C. T., Koike, T. E., Ozaki, G. A. T., Castoldi, R. C., \& Camargo Filho, J. C. S. (2017). Histological analysis of the association of low level laser therapy and platelet-rich plasma in regeneration of 
muscle injury in rats. Brazilian Journal of Physical Therapie, 21(6), 425-433. https://doi.org/10.1016/j.bjpt. 2017.06.007

Garduño-Ramón, M., Vega-Mancilla, S. G., Morales-Henández, A., \& Osornio-Rios, R. A. (2017). Supportive Noninvasive Tool for the Diagnosis of Breast Cancer Using a Thermographic Camera as Sensor. Sensors (Basel), 17(3), 497. https://doi.org/10.3390/s17030497

Gerardi, B. (2016). Profile of serum cytokines and thermography in quarter-mile horses submitted to double loop testing (Doctoral Thesis, São Paulo State University (UNESP), Faculdade de Medicina Veterinária, Campus Araçatuba, São Paulo, Brazil). Retrived from http://hdl.handle.net/11449/142832

Girardi, A. M. (2016). Subacute ruminal acidosis in Santa inês sheep: Clinical, laboratory and evaluation of laminitis by infrared thermography and digital radiology (Doctoral Thesis, São Paulo State University (UNESP), Faculdade de Ciências Agrárias e Veterinária, Campus Jaboticabal, São Paulo, Brazil). Retrived from https://repositorio.unesp.br/handle/11449/134272

Gravena, K. (2010). Evaluation of the integrity of the dermal and epidermal tissues of the hoof of horses collected by dorsal trans-mural access (Masters Thesis, São Paulo State University (UNESP), Faculdade de Ciências Agrárias e Veterinária, Campus Jaboticabal, São Paulo, Brazil). Retrived From https://repositorio. unesp.br/handle/11449/89050

Grossbard, P. B., Loughin, C. A., Marino, Dominic, D. J., Marino, L. J., Sackman, J., Umbaugh, S. E., ... Akerman, M. (2014). Medical infrared imaging (thermography) of type I Thoracolumbar Disk Disease in Chondrodystrophic Dogs. Veterinary Surgery, 43(7), 869-876. https://doi.org/10.1111/j.1532-950X.2014. 12239.x

Hill, R. W., Wyse, G. A., \& Anderson, M. (2012). Animal Physiology (2nd ed.). Porto Alegre, RS: Artmed.

Hogan, D. F., Fox, P. R., Jacob, K., Keene, B., Laste, N. J., Rosenthal, S., ... Hsin-Weng, H. (2015). Secondary prevention of cardiogenic arterial thromboembolism in the cat: The double-blind, randomized, positive-controlled feline arterial thromboembolism; clopidogrel vs. Aspirin trial (FAT CAT). Journal of Veterinary Cardiology, 17. https://doi.org/10.1016/j.jvc.2015.10.004

Jacob, F. G., Baracho, M. S., Nääs, I. A., Souza, R., \& Salgado, D. A. (2016). The use of infrared thermography in the identification of pododermatitis in broilers. Engenharia Agricola, 36(2), 253-259. https://doi.org/ 10.1590/1809-4430-Eng.Agric.v36n2p253-259/2016

Leite, G. P. M. F., Neves, L. M. S., Silva, C. A., Guirro, R. R. J., Souza, T. R., Souza, A. K., ... Guirro, E. C. O. (2017). Photobiomodulation laser and pulsed electrical field increase the viability of the musculocutaneous flap in diabetic rats. Lasers in Medical Sciencie, 32, 641-648. https://doi.org/10.1007/s10103-017-2160-7

Lloyd, J. K.F. (2017). Minimising Stress for Patients in the Veterinary Hospital: Why It Is Important and What Can Be Done about It. Veterinary Sciences, 4(22). https://doi.org/10.3390/vetsci4020022

Magalhaes, C., Vardasca, R., \& Mendes, J. (2018). Recent use of medical infrared thermography in skin neoplasms. Skin Research Technology, 1-3. https://doi.org/10.1111/srt.12469

Matera, J. M., Dagf, M. L. Z., \& Pereira, D. B. (1994). Effects of soft-laser (diode) radiation on the healing process in felines. Revista Brasileira de Pesquisa e Ciência Veterinária, 31(1), 43-8.

Matsui, Y., Murayama, R., Tanabe, H., Oe, M., Motoo, Y., Wagatsuma, T., ... Sanada, H. (2017). Evaluation of the Predictive Validity of Thermography in Identifying Extravasation with Intravenous Chemotherapy Infusions. Journal of Infusion Nursing, 40(6), 367-374. https://doi.org/10.1097/NAN.0000000000000250

Melo, S. R. (2013). Prognostic factors in canine mastocytoma: Correlation between clinical, histological parameters, proliferation markers and thermographic analysis (Master's Thesis, Faculdade de Medicina Veterinária e Zootecnia, University of São Paulo, São Paulo, Brazil).

Milosevic, M., Jankovic, D., \& Peulic, A. (2014). Thermography based breast cancer detection using texture features and minimum variance quantization. Excli Journal, 13, 1204-1215.

Moura, D. J., Maia, A. P. A., Vercellino, R. A., Medeiros, B. B. L., Sarubbi, J., \& Grisk, P. R. (2011). Use of infrared thermography in the analysis of horse thermoregulation in training. Engenharia Agrícola, 31(1), 23-32. https://doi.org/10.1590/S0100-69162011000100003

Nascimento, G. R., Nääs, I. A., Baracho, M. S., Pereira, D. F., \& Neves, D. P. (2014). Infrared thermography in the thermal comfort estimation of broilers. Jornal Brasileiro de Agricultura e Engenharia Ambiental, 18(6), 658-663. https://doi.org/10.1590/S1415-43662014000600014 
Nina, M. I. D. (2012). Comparative thermographic evaluation of the integral knee joint and of dogs submitted to two corrective osteotomy techniques for joint stabilization after cranial cruciate ligament rupture (Doctoral Dissertation, Faculdade de Medicina Veterinária e Zootecnina, University of São Paulo, São Paulo, Brazil).

Nomura, R. H. C. (2015). Studies of the application of thermography in knees and vertebral columns of dogs (Master's Thesis, Federal University of Paraná, Paraná, Brazil). Retrived from http://hdl.handle.net/1884/ 40121

Oliveira, I. V. P. P., \& Dias, R. V. C. (2012). Wound healing: Phases and factors of influence. Acta Veterinaria Brasilica, 6(4), 267-271.

Oliveira, L. O., Pippi, N. L., Grace, D. L., Faria, R. X., Guimarães, L. D., Guedes, A. G. P., \& Alexandre Mazzanti, A. (2000). Pediculated Flap of large dorsal muscle for repair aexperimental diaphragmatic defect in dogs. Ciência Rural Santa Maria, 30(6), 1005-1009. https://doi.org/10.1590/S0103-84782000000600014

Palveski, M., Silva, D. M., Leite, N. C., Junior, D. A., Sousa, R. S., Guérios, S. D., \& Dornbusch, P. T. (2015). Infrared Thermography in Dogs with Mammary Tumors and Healthy Dogs. Journal of Veterinary Internal Medicine, 29(6), 1578-1583. https://doi.org/10.1111/jvim.13597

Paulo, N. M., Lima, F. G., Siqueira Júnior, J. T., Fleury, L. F. F., Sant 'Ana, F. J., Borges, A. C., \& Telles, T. C. (2005). Rubber latex membrane (Hevea brasiliensis), with and without $0.1 \%$ polylysine and marlex screen in the reconstruction of iatrogenic defects of the abdominal wall of rats. Acta Cirúrgica Brasileira, 20(4), 305-310. https://doi.org/10.1590/S0102-86502005000400008

Pavletic, M. M. (2010). Small Animal Wound Management and Reconstructive Surgery (3rd ed.). Iowa: Wiley-Blackwell.

Pazzini, J. M., De Nardi, A. B., Huppes, R. R., Gering, A. P., Ferreira, M. G. P. A., Silveira, C. P. B., ... Oliveira, J. A. (2016). Use of platelet-rich plasma for the stimulation of angiogenesis in axial thoracodorsal flap angulation in rabbits (Oryctolagus cuniculus). Pesquisa Veterinária Brasileira, 36(2), 108-118. https://doi.org/10.1590/s0100-736x2017000500001

Pimentel, M. M. L., Santos, F. A., Teixeira, A. C. G., Izzo, R. G., Lima, M. A., Macedo, M. F., \& Bezerra, M. B. (2017). Biochemical, thermographic, and follicular responses of murine models of hormone-treated bovine ovarian renal capsule xenografts. Pesquisa Veterinária Brasileira, 37(5), 425-431. https://doi.org/10.1590/ s0100-736x2017000500001

Pontes, S. M. M., Melo, L. H. De P., Maia, N. P. De S., Nogueira, A., Da, N. C., Vasconcelos, T. B., ... Holanda, M. A. (2017). Influence of the ventilatory mode on acute adverse effects and facial thermography after noninvasive ventilation. Jornal Brasileiro de Pneumologia, 43(2), 87-94. https://doi.org/10.1590/s180637562016000000172

Portugal, E. S. (2014). Thermography and Doppler ultrasonography of the pampiniform plexus and thermography of the scrotum of bulls: correlation with the quality of the semen (Doctorals Thesis, São Paulo State University, Faculdade de Ciências Agrárias e Veterinária, Campus Jaboticabal, São Paulo, Brazil). Retrived from http://hdl.handle.net/11449/121877

Rabelo, S. B., Villaverde, A. B., Nicolau, R. A., Salgado, M. A. C., Melo, M. S., \& Pacheco, M. T. T. (2006). Comparison between wound healing in induced diabetic and nondiabetic rats after low-level laser therapy. Photomedicine and Laser Surgery, 24(4), 474-479. https://doi.org/10.1089/pho.2006.24.474

Rathmann, P., Chalopin, C., Halama, D., Giri, P., Meixensberger, J., \& Lindner, D. (2017). Dynamic infrared thermography (DIRT) for assessment of skin blood perfusion in cranioplasty: A proof of concept for qualitative comparison with the standard indocyanine green video angiography (ICGA). International Journal of Computer Assisted Radiology and Surgery. https://doi.org/10.1007/s11548-017-1683-5

Redaelli, V., Tanzi, B., Fabio Luzi, F., Stefanello, D., Proverbio, D., Crosta, L., \& Di Giancamillo, M. (2014). Use of thermographic imaging in clinical diagnosis of small animal: Preliminary notes. Annali dell'Istituto Superiore di Sanità, 50(2), 140-146.

Reece, W. O. (2008). Function Anatomy and Physiology of Domestic Animals (3rd ed.). São Paulo: Roca.

Roberto, J. V. B. (2012). Effect of the thermal environment and the use of infrared thermography in saanen goats and their mestizos with the boer in the Brazilian semi-arid region (Master's Thesis, Centro de saúde e Técnologia, Federal University of Campina Grande). 
Rocha Júnior, A. M., Oliveira, R. G., Farias, R. E., Andrade, L. C. F., \& Arestrup, F. M. (2006). Modulation of fibroblast proliferation and inflammatory response by low intensity laser therapy in the tissue repair process. Anais Brasileiro de Dermatologia, 81(2), 150-156. https://doi.org/10.1590/S0365-05962006000200006

Schlager, O., Gschwandtner, M. E., Herberg, K., Frohner, T., Schillinger, M., Koppensteiner, R., \& Mlekusch, W. (2010). Correlation of infrared thermography and skin perfusion in Raynaud patients and in healthy controls. Microvascular Research, 80, 54-57. https://doi.org/10.1016/j.mvr.2010.01.010

Silva, E. M., Gomes, S. P., Ulbrich, L. M., \& Giovanini, A. F. (2007). Histological evaluation of low intensity laser therapy in the healing of epithelial, connective and bone tissues: Experimental study in rats. Revista Sul-Brasileira de Odontologia, 4(2).

Shiel, R. E., Pinilla, M., Mcallister, H., \& Mooney, C. T. (2012). Assessment of the value of quantitative thyroid scintigraphy for determination of thyroid function in dogs. Journal of Small Animal Practice, 53, 278-285. https://doi.org/10.1111/j.1748-5827.2011.01205.x

Slatter, D. (2007). Textbook of Small Animal Surgery (3rd ed.). São Paulo: Manole.

Stampfli, S. F., Camici, G. G., Keller, S., Rozenberg, I., Arras, M., Schuler, B., ... Tanner, F. C. (2014). Restraint stress enhances arterial thrombosis in vivo-Role of the sympathetic nervous system. Stress, 17(1), 126-132. https://doi.org/10.3109/10253890.2013.862616

Tatmatsu-Rocha, J. C., Ferraresi, C., Hamblin, M. R., Maia, F. D., Nascimento, N. R. F., Driusso, P., \& Parizotto, N. A. (2016). Low-level laser therapy $(904 \mathrm{~nm})$ can increase collagen and reduce oxidative and nitrosative stress in diabetic wounded mice. Skin Journal of Photochemistry \& Photobiology, 164, 96-102. https://doi.org/10.1016/j.jphotobiol.2016.09.017

Tenorio, X., Ajay, L., Mahajan, A. L., Wettstein, R., Harder, Y., Pawlovski, M., \& Pittet, B. (2009). Early Detection of Flap Failure Using a New Thermographic Device. Journal of Surgical Research, 151, 15-21. https://doi.org/10.1016/j.jss.2008.03.001

Tepper, M., \& Gannot, I. (2015). Monitoring tumor state from thermal images in animal and human models. Medical Physics, 42(3). https://doi.org/10.1118/1.4907967

Trindade, J. T. (2009). Use of reconstructive surgery in the treatment of open cutaneous wounds in dogs and cats. Faculdade de Medicina Veterinária, Federal University of Rio Grande do Sul. Retrived from http://hdl.handle.net/10183/22929

Zanghi, B. M., Cupp, C. J., Pan, Y., Tissot-Favre, D. G., Milgram, N. W., Nagy, T. R., \& Dobson, H. (2013). Noninvasive measurements of body composition and body water via quantitative magnetic resonance, deuterium water, and dual-energy x-ray absorptiometry in awake and sedated dogs. Amerian Journal of Veterinarian Research, 74(5). https://doi.org/10.2460/ajvr.74.5.733

\section{Copyrights}

Copyright for this article is retained by the author(s), with first publication rights granted to the journal.

This is an open-access article distributed under the terms and conditions of the Creative Commons Attribution license (http://creativecommons.org/licenses/by/4.0/). 